\title{
Fluorine F 18 Integrin Alpha v Beta 6- targeted Peptide
}

National Cancer Institute

\section{Source}

National Cancer Institute. Fluorine F18 Integrin Alpha v Beta 6-targeted Peptide. NCI

Thesaurus. Code C150392.

A radiotracer composed of an integ rin alphaVbeta6 (aVb6) binding peptide (BP) radiolabeled with the radionuclide fluorine $F$ 18, with potential integ rin aVb6 imaging activity using positron emission tomography (PET). Upon administration, the fluorine F 18 integrin aVb6-targeted peptide selectively binds to integ rin aVb6-positive cancer cells. During PET, aVb6-expressing tumor cells can be visualized and the degree of tumor growth can be determined. Integrin aVb6, a cell adhesion and signaling receptor, is upregulated in certain cancer cell types and has been associated with increased proliferation, migration and invasion of tumor cells. 